\title{
Asuhan Keperawatan Jiwa Pada Tn. A Dengan Gangguan Proses Pikir : Waham Kebesaran Di Yayasan Pemenang Jiwa Sumatera
}

\author{
Endang Rotua Pakpahan
}

erotuapakpahan@gmail.com

\section{BAB 1}

\section{PENDAHULUAN}

\subsection{Latar Belakang}

Skizofrenia merupakan suatu gangguan jiwa berat yang bersifat kronis yang ditandai dengan ganggguan komunikasi, gangguan realitas (halusinasi atau waham), afek tidak wajar atau tumpul, gangguan fungsi kognitif serta mengalami kesulitan dalam melakukan aktivitas sehari-hari (Keliat, 2015). Gejala skizofrenia dapat mengalami perubahan semakin membaik atau semakin memburuk dalam kurun waktu tertentu, hal tersebut berdampak dengan hubungan pasien dengan dirinya sendiri serta orang yang dekat dengan penderita (Pardede, Keliat \& Wardani, 2015).

Skizofrenia adalah gangguan yang berlangsung selama minimal 6 bulan dan mencakup setidaknya 1 bulan gejala fase aktif. Sementara itu gangguan skizofrenia dikarakteristikan dengan gejala positif (delusi dan halusinasi), gejala negatif (apatis, menarik diri, penurunan daya pikir, dan penurunan afek), dan gangguan kognitif (memori, perhatian, pemecahan masalah, dan sosial) (Hendarsyah, 2016). Salah satu jenis gangguan jiwa skizofrenia adalah skizofrenia paranoid. Secara klasik skizofrenia tipe paranoid ditandai terutama oleh adanya gangguan waham. Waham merupakan salah satu gangguan orientasi realitas. Gangguan orientasi realitas adalah ketidakmampuan klien menilai dan berespons pada realitas (Sofian, 2017).

Menurut data yang didapat oleh WHO (2009 dalam Pardede, 2016), diperkirakan 450 juta orang diseluruh dunia mengalami gangguan jiwa, sekitar $10 \%$ orang 
dewasa akan mengalami gangguan jiwa saat ini dan $25 \%$ penduduk diperkirakan akan mengalami gangguan jiwa pada usia tertentu selama hidupnya. Gangguan jiwa mencapai $13 \%$ dari penyakit secara keseluruhan dan kemungkinan akan berkembang menjadi $25 \%$ ditahun 2030. Prevalensi skizofrenia yang cukup tinggi bukan hanya di dunia tetapi di Indonesia juga mengalami hal yang sama. Penelitian Pardede, Keliat \& Wardani (2015) mendapatkan hasil kelompok skizofrenia juga menempati sebesar $83.3 \%$ klien di rumah sakit jiwa RSJ Daerah Provinsi Sumatera Utara Medan.

Gangguan proses pikir waham biasanya dianggap sulit untuk diobati (Skelton, 2015). Pada populasi umum gangguan proses pikir waham memiliki prevalensi sekitar $0,18 \%$, sedangkan prevalensi pada rawat inap psikiatris antara 1 dan $4 \%$. Prevalensi gangguan proses pikir waham sebenarnya cenderung lebih tinggi, dikarenakan kurangnya wawasan dalam mencegah serta mencari bantuan dalam mengenali penyakit tersebut (Rowland, 2019). Penelitian yang dilakukan Christenson, dkk. Di sebuah komunitas orang tua di San Francisco, mereka yang dinilai memiliki gangguan kejiwaan mengalami gejala kecurigaan sebanyak $17 \%$ dan yang memiliki gangguan proses pikir waham sebanyak 13\% (Asis, 2018).

Menurut Bell (2019 dalam Prakasa, 2020) Gangguan proses pikir waham merupakan suatu keyakinan yang sangat mustahil dan dipegang teguh walaupun tidak memiliki bukti-bukti yang jelas, dan walaupun semua orang tidak percaya dengan keyakinannya. Waham sendiri terbagi menjadi lima macam, yaitu waham kebesaran, waham curiga, waham keagamaan, waham somatik, dan waham nihilistik. Gangguan proses pikir waham ini adalah gejala positif dari skizofrenia dan biasanya orang yang memiliki gejala tersebut akan melakukan hal-hal yang sesuai dengan jenis wahamnya, yaitu dengan memiliki rasa curiga yang tinggi terhadap diri sendiri maupun orang lain, merasa memiliki kekuasaan yang besar, merasa mempunyai kekuatan yang luar biasa jauh diatas manusia pada umumnya, merasa dirinya mempunyai penyakit yang sangat parah atau dapat menular ke orang lain, serta menganggap dirinya sudah meninggal. Gangguan proses pikir waham ditandai oleh adanya setidaknya selama satu bulan mengalami waham dan 
tidak adanya gejala lain yang biasanya termasuk waham itu sendiri. Waham juga dikategorikan menjadi dua yaitu waham non bizarre dan waham bizarre. waham non bizarre merupakan kepercayaan yang bisa dibayangkan dengan benar atau nyata, misalnya pasangan hidup yang berselingkuh dan merasa dimata-matai oleh lembaga pemerintah. Sedangkan waham bizarre tidak memiliki dasar yang memungkinkan dalam kehidupan nyata, seperti mengganti semua organ tubuh seseorang tanpa melakukan operasi (Statistical, 2019).

Dalam beberapa penelitian dijelaskan bahwa orientasi realita dapat meningkatkan fungsi perilaku. Pasien perlu dikembalikan pada realita bahwa hal-hal yang dikemukakan tidak berdasarkan fakta dan belum dapat diterima orang lain dengan tidak mendukung ataupun membantah waham. Tidak jarang dalam proses ini pasien mendapatkan konfrontasi dari lingkungan terkait pemikiran dan keyakinannya yang tidak realistis. Hal tersebut akan memicu agresifitas pasien waham. Reaksi agresif ini merupakan efek dari besarnya intensitas waham yang dialami pasien. Salah satu cara untuk mengontrol perilaku agresif dari pasien waham yaitu dengan memberi asuhan keperawatan jiwa (Keliat, 2019). Pemberian intervensi keperawatan jiwa pada pasien dengan waham berfokus pada orientasi realita, menstabilkan proses pikir, dan keamanan (Townsend, 2015). Data yang diperoleh dari Medical Record Yayasan Pemenang Jiwa Sumatera tahun 2021, pasien yang menderita skizofrenia sebanyak 70 Orang. Dari jumlah pasien tersebut yang menjadi subjek di pembuatan askep ini adalah 1 orang dengan pasien gangguan proses pikir : Waham (Waham Kebesaran) berinisial Tn. A. Maka tujuan asuhan keperawatan yang akan di lakukan ialah untuk mengajarkan strategi pelaksanaan Waham pada Tn. A.

\subsection{Rumusan Masalah}

Berdasarkan masalah yang telah dipaparkan pada latar belakang maka rumusan masalah dalam askep ini yaitu : Asuhan Keperawatan Jiwa Pada Tn. A Dengan Gangguan Proses Proses Pikir : Waham Kebesaran Di Yayasan Pemenang Jiwa Sumatera. 


\subsection{Tujuan}

\subsubsection{Tujuan umum}

Mahasiswa mampu menerapkan asuhan keperawan jiwa pada Tn. A dengan Waham Kebesaran di Yayasan Pemenang Jiwa Sumatera Sumatera.

\subsubsection{Tujuan Khusus}

Setelah melakukan asuhan keperawatan kepada klien dengan Waham Kebesaran, mahasiswa/i diharapkan mampu :

1. Mahasiswa mampu mengetahui defenisi, penyebab, tanda dan gejala, rentang respon dan penatalaksanaan pada klien Waham Kebesaran

2. Mahasiswa mampu melakukan pengkajian, analisa data pada Tn. A dengan Waham Kebesaran di Yayasan Pemenang Jiwa Sumatera.

3. Mahasiswa mampu menegakkan diagnosa keperawatan pada Tn. A dengan Waham Kebesaran di Yayasan Pemenang Jiwa Sumatera.

4. Mahasiswa mampu menetapkan intervensi keperawatan pada Tn. A dengan Waham Kebesaran di Yayasan Pemenang Jiwa Sumatera.

5. Mahasiswa mampu melakukan implementasi keperawatan pada Tn. A dengan Waham Kebesaran di Yayasan Pemenang Jiwa Sumatera.

6. Mahasiswa mampu mengevaluasi hasil asuhan keperawatan pada Tn. A dengan Waham Kebesaran di Yayasan Pemenang Jiwa Sumatera.

7. Mahasiswa mampu melakukan pendokumentasian pada Tn. A dengan Waham Kebesaran di Yayasan Pemenang Jiwa Sumatera.

\subsection{Manfaat}

\section{Pasien}

Diharapkan tindakan yang telah di ajakarkan dapat di terapkan secara mandiri untuk mengontrol emosi dan untuk mendukung kelangsungan kesehatan pasien.

\section{Keluarga}

Diharapkan keluarga dapat memberikan dukungan moral, emosional dan spiritual serta membantu dalam menerapkan asuhan keperawatan jiwa kepada pasien dengan masalah risiko perilaku kekerasan 


\section{Institusi Pendidikan}

Bagi institusi pendidikan diharapkan untuk menjadi acuan dalam dalam melakukan kegiatan kemahasiswaan dalam bidang keperawatan jiwa.

\section{Yayasan Pemenang Jiwa Sumatera}

Diharapkan dapat menjadi acuan dalam menanganin atau dalam memberikan pelayanan kepada pasien dengan gangguan jiwa dengan perilaku kekerasan di Yayasan Pemenang Jiwa Sumatera. 


\section{BAB 2}

\section{TINJAUAN TEORITIS}

\subsection{Konsep Waham}

\subsubsection{Definisi}

Waham adalah keyakinan yang salah yang didasarkan oleh kesimpulan yang salah tentang realita eksternal dan dipertahankan dengan kuat. Waham merupakan gangguan dimana penderitanya memiliki rasa realita yang berkurang atau terdistorsi dan tidak dapat membedakan yang nyata dan yang tidak nyata (Victoryna, 2020)

Gangguan proses pikir waham merupakan suatu keyakinan yang sangat mustahil dan dipegang teguh walaupun tidak memiliki bukti-bukti yang jelas, dan walaupun semua orang tidak percaya dengan keyakinannya (Bell, 2019)

\subsubsection{Etiologi}

Menurut World Health Organization (2016) secara medis ada banyak kemungkinan penyebab waham, termasuk gangguan neurodegeneratif, gangguan sistem saraf pusat, penyakit pembuluh darah, penyakit menular, penyakit metabolisme, gangguan endokrin, defisiensi vitamin, pengaruh obat-obatan, racun, dan zat psikoaktif.

a. Faktor Predisposisi

1. Biologis

Pola keterlibatan keluarga relative kuat yang muncul di kaitkan dengan delusi atau waham. Dimana individu dari anggota keluarga yang di manifestasikan dengan gangguan ini berada pada resiko lebih tinggi untuk mengalaminya di bandingkan dengan populasi umum.Studi pada manusia kembar juga menunjukan bahwa ada keterlibatan factor. 


\section{Teori Psikososial}

\section{a. System Keluarga}

Perkembangan skizofrenia sebagai suatu perkembangan disfungsi keluarga.Konflik diantara suami istri mempengaruhi anak. Bayaknya masalah dalam keluarga akan mempengaruhi perkembangan anak dimana anak tidak mampu memenuhi tugas perkembangan dimasa dewasanya. Beberapa ahli teori menyakini bahwa individu paranoid memiliki orang tua yang dingin, perfeksionis, sering menimbulkan kemarahan,perasaan mementingkan diri sendiri yang berlebihan dan tidak percaya pada individu. Klien menjadi orang dewasa yang rentan karena pengalaman awal ini.

\section{Teori Interpersonal}

Dikemukakan oleh Priasmoro (2018) di mana orang yang mengalami psikosis akan menghasilkan suatu hubungan orang tua-anak yang penuh dengan ansietas tinggi.Hal ini jika di pertahankan maka konsep diri anak akan mengalami ambivalen.

\section{Psikodinamika}

Perkembangan emosi terhambat karena kurangnya rangsangan atau perhatian ibu,dengan ini seorang bayi mengalami penyimpangan rasa aman dan gagal untuk membangun rasa percayanya sehingga menyebabkan munculnya ego yang rapuh karena kerusakan harga diri yang parah,perasaan kehilangan kendali,takut dan ansietas berat.Sikap curiga kepada seseorang di manifestasikan dan dapat berlanjut di sepanjang kehidupan. Proyeksi merupakan mekanisme koping paling umum yang di gunakan sebagai pertahanan melawan perasaan

Faktor- faktor yang mempengaruhi terjadinya waham adalah:

1. Gagal melalui tahapan perkembangan dengan sehat.

2. Disingkirkan oleh orang lain dan merasa kesepian

3. Hubungan yang tidak harmonis dengan orang lain

4. Perpisahan dengan orang yang di cintainya 
5. Kegagalan yang sering di alami

6. Keturunan,paling sering pada kembar satu telur

7. Menggunakan penyelesaian masalah yang tidak sehat misalnya menyalahkan orang lain.

\section{b. Faktor Presipitasi}

\section{Biologi}

Stress biologi yang berhubungan dengan respon neurologik yang maladaptif termasuk:

a) Gangguan dalam putaran umpan balik otak yang mengatur proses informasi

b) Abnormalitas pada mekanisme pintu masuk dalam otak yang mengakibatkan ketidakmampuan untuk secara selektif menanggapi rangsangan.

2. Stres lingkungan

Stres biologi menetapkan ambang toleransi terhadap stress yang berinteraksi dengan stressor lingkungan untuk menentukan terjadinya gangguan perilaku.

3. Pemicu gejala

Pemicu merupakan prekursor dan stimulus yang yang sering menunjukkan episode baru suatu penyakit. Pemicu yang biasa terdapat pada respon neurobiologik yang maladaptif berhubungan dengan kesehatan. Lingkungan, sikap dan perilaku individu (Direja, 2011) 


\subsubsection{Rentang Respon}

Menurut Darmiyanti (2012), rentang respon waham sebagai berikut :

Respon adaptif

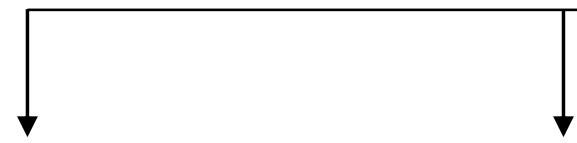

Pikiran logis

Persepsi Akurat

Emosi Konsisten

Prilaku Sesuai

Berhubungan Social
Disorientasi Pikiran

Ilusi

Reaksi Emosi Ber (+/-)

Prilaku Aneh/Tdk Biasa

Menarik Diri
Respon Maladaptif

\section{Gg.Pikiran/Waham}

Sulit Berespon

Perilaku Kacau

Isolasi Sosial

\subsubsection{Fase Waham}

Menurut Eriawan (2019) Proses terjadinya waham dibagi menjadi enam yaitu :

\section{a. Fase Lack of Human need}

Waham diawali dengan terbatasnya kebutuhan-kebutuhan klien baik secara fisik maupun psikis. Secara fisik klien dengan waham dapat terjadi pada orang-orang dengan status sosial dan ekonomi sangat terbatas. Biasanya klien sangat miskin dan menderita. Keinginan ia untuk memenuhi kebutuhan hidupnya mendorongnya untuk melakukan kompensasi yang salah. Ada juga klien yang secara sosial dan ekonomi terpenuhi tetapi kesenjangan antara Reality dengan selfideal sangat tinggi. Misalnya ia seorang sarjana tetapi menginginkan dipandang sebagai seorang dianggap sangat cerdas, sangat berpengalaman dan diperhitungkan dalam kelompoknya. Waham terjadi karena sangat pentingnya pengakuan bahwa ia eksis di dunia ini. Dapat dipengaruhi juga oleh rendahnya penghargaan saat tumbuh kembang (life span history).

b. Fase lack of self esteem

Tidak ada tanda pengakuan dari lingkungan dan tingginya kesenjangan antara self ideal dengan self reality (kenyataan dengan 
harapan) serta dorongan kebutuhan yang tidak terpenuhi sedangkan standar lingkungan sudah melampaui kemampuannya. Misalnya, saat lingkungan sudah banyak yang kaya, menggunakan teknologi komunikasi yang canggih, berpendidikan tinggi serta memiliki kekuasaan yang luas, seseorang tetap memasang self ideal yang melebihi lingkungan tersebut. Padahal self reality-nya sangat jauh. Dari aspek pendidikan klien, materi, pengalaman, pengaruh, support system semuanya sangat rendah.

c. Fase control internal external

Klien mencoba berfikir rasional bahwa apa yang ia yakini atau apaapa yang ia katakan adalah kebohongan, menutupi kekurangan dan tidak sesuai dengan kenyataan. Tetapi menghadapi kenyataan bagi klien adalah sesuatu yang sangat berat, karena kebutuhannya untuk diakui, kebutuhan untuk dianggap penting dan diterima lingkungan menjadi prioritas dalam hidupnya, karena kebutuhan tersebut belum terpenuhi sejak kecil secara optimal. Lingkungan sekitar klien mencoba memberikan koreksi bahwa sesuatu yang dikatakan klien itu tidak benar, tetapi hal ini tidak dilakukan secara adekuat karena besarnya toleransi dan keinginan menjaga perasaan. Lingkungan hanya menjadi pendengar pasif tetapi tidak mau konfrontatif berkepanjangan dengan alasan pengakuan klien tidak merugikan orang lain.

d. Fase environment support

Adanya beberapa orang yang mempercayai klien dalam lingkungannya menyebabkan klien merasa didukung, lama kelamaan klien menganggap sesuatu yang dikatakan tersebut sebagai suatu kebenaran karena seringnya diulang-ulang. Dari sinilah mulai terjadinya kerusakan kontrol diri dan tidak berfungsinya norma ( Super Ego ) yang ditandai dengan tidak ada lagi perasaan dosa saat berbohong. 


\section{e. Fase comforting}

Klien merasa nyaman dengan keyakinan dan kebohongannya serta menganggap bahwa semua orang sama yaitu akan mempercayai dan mendukungnya. Keyakinan sering disertai halusinasi pada saat klien menyendiri dari lingkungannya. Selanjutnya klien lebih sering menyendiri dan menghindar interaksi sosial (Isolasi sosial).

\section{f. Fase improving}

Apabila tidak adanya konfrontasi dan upaya-upaya koreksi, setiap waktu keyakinan yang salah pada klien akan meningkat. Tema waham yang muncul sering berkaitan dengan traumatik masa lalu atau kebutuhan-kebutuhan yang tidak terpenuhi (rantai yang hilang). Waham bersifat menetap dan sulit untuk dikoreksi. Isi waham dapat menimbulkan ancaman diri dan orang lain. Penting sekali untuk mengguncang keyakinan klien dengan cara konfrontatif serta memperkaya keyakinan relegiusnya bahwa apaapa yang dilakukan menimbulkan dosa besar serta ada konsekuensi sosial.

\subsubsection{Jenis Waham}

Menurut Stuart (2005 dalam Prakasa, 2020) jenis waham yaitu :

a. Waham kebesaran: individu meyakini bahwa ia memiliki kebesaran atau kekuasaan khusus yang diucapkan berulang kali, tetapi tidak sesuai kenyataan. Misalnya, "Saya ini pejabat di separtemen kesehatan lho!" atau, "Saya punya tambang emas."

b. Waham curiga: individu meyakini bahwa ada seseorang atau kelompok yang berusaha merugikan/mencederai dirinya dan siucapkan berulang kali, tetapi tidak sesuai kenyataan. Contoh, "Saya tidak tahu seluruh saudara saya ingin menghancurkan hidup saya karena mereka iri dengan kesuksesan saya."

c. Waham agama: individu memiliki keyakinan terhadap terhadap suatu agama secara berlebihan dan diucapkan berulang kali, tetapi 
tidak sesuai kenyataan. Contoh, "Kalau saya mau masuk surga, saya harus menggunakan pakaian putih setiap hari."

d. Waham somatic: individu meyakini bahwa tubuh atau bagian tubuhnya terganggu atau terserang penyakit dan diucapkan berulang kali, tetapi tidak sesuai dengan kenyataan. Misalnya, "Saya sakit kanker." (Kenyataannya pada pemeriksaan laboratorium tidak ditemukan tanda-tanda kanker, tetapi pasien terus mengatakan bahwa ia sakit kanker).

e. Waham nihilistik: Individu meyakini bahwa dirinya sudah tidak ada di dunia/meninggal dan diucapkan berulang kali, tetapi tidak sesuai kenyataan. Misalnya, "Ini kan alam kubur ya, semua yang ada disini adalah roh-roh".

f. Waham sisip pikir : keyakinan klien bahwa ada pikiran orang lain yang disisipkan ke dalam pikirannya.

g. Waham siar pikir : keyakinan klien bahwa orang lain mengetahui apa yang dia pikirkan walaupun ia tidak pernah menyatakan pikirannya kepada orang tersebut

h. Waham kontrol pikir : keyakinan klien bahwa pikirannya dikontrol oleh kekuatan di luar dirinya.

\subsubsection{Tanda dan Gejala}

Menurut Herman (2011 dalam Prakasa, 2020) bahwa tanda dan gejala gangguan proses pikir waham terbagi menjadi 8 gejala yaitu, menolak makan, perawatan diri, emosi, gerakan tidak terkontrol, pembicaraan tidak sesuai, menghindar, mendominasi pembicaraan, berbicara kasar.

1. Waham Kebesaran

a. DS : Klien mengatakan bahwa ia adalah presiden, Nabi, Wali, artis dan lainnya yang tidak sesuai dengan kenyataan dirinya.

b. DO :

1) Perilaku klien tampak seperti isi wahamnya 
2) Inkoheren ( gagasan satu dengan yang lain tidak logis, tidak berhubungan, secara keseluruhan tidak dapat dimengerti

3) Klien mudah marah

4) Klien mudah tersinggung

2. Waham Curiga

a. DS :

1) Klien curiga dan waspada berlebih pada orang tertentu

2) Klien mengatakan merasa diintai dan akan membahayakan dirinya.

b. DO :

1) Klien tampak waspada

2) Klien tampak menarik diri

3) Perilaku klien tampak seperti isi wahamnya

4) Inkoheren ( gagasan satu dengan yang lain tidak logis, tidak berhubungan, secara keseluruhan tidak dapat dimengerti )

3. Waham Agama

a. DS :

Klien yakin terhadap suatu agama secara berlebihan, diucapkan berulang-ulang tetapi tidak sesuai dengan kenyataan.

b. DO :

1) Perilaku klien tampak seperti isi wahamnya

2) Klien tampak bingung karena harus melakukan isi wahamnya

3) Inkoheren (gagasan satu dengan yang lain tidak logis, tidak berhubungan, secara keseluruhan tidak dapat dimengerti)

4. Waham Somatik

a. DS :

1) Klien mengatakan merasa yakin menderita penyakit fisik

2) Klien mengatakan merasa khawatir sampai panik 
b. DO :

1) Perilaku klien tampak seperti isi wahamnya

2) Inkoheren ( gagasan satu dengan yang lain tidak logis, tidak berhubungan, secara keseluruhan tidak dapat dimengerti )

3) Klien tampak bingung

4) Klien mengalami perubahan pola tidur

5) Klien kehilangan selera makan

5. Waham Nihilistik

a. DS :

Klien mengatakan bahwa dirinya sudah meninggal dunia, diucapkan berulang-ulang tetapi tidak sesuai dengan kenyataan.

b. DO :

1) Perilaku klien tampak seperti isi wahamnya

2) Inkoheren ( gagasan satu dengan yang lain tidak logis, tidak berhubungan, secara keseluruhan tidak dapat dimengerti )

3) Klien tampak bingung

4) Klien mengalami perubahan pola tidur

5) Klien kehilangan selera makan

6. Waham Bizzare

a. Sisip Pikir :

1) DS :

a) Klien mengatakan ada ide pikir orang lain yang disisipkan dalam pikirannya yang disampaikan secara berulang dan tidak sesuai dengan kenyataan.

b) Klien mengatakan tidak dapat mengambil keputusan

2) $\mathrm{DO}:$

a) Perilaku klien tampak seperti isi wahamnya

b) Klien tampak bingung

c) Inkoheren (gagasan satu dengan yang lain tidak logis, tidak berhubungan, secara keseluruhan tidak dapat dimengerti)

d) Klien mengalami perubahan pola tidur 
b. Siar Pikir

1) DS :

a) Klien mengatakan bahwa orang lain mengetahui apa yang dia pikirkan yang dinyatakan secara berulang dan tidak sesuai dengan kenyataan.

b) Klien mengatakan merasa khawatir sampai panik

c) Klien tidak mampu mengambil keputusan

2) $\mathrm{DO}:$

a) Klien tampak bingung

b) Perilaku klien tampak seperti isi wahamnya

c) Inkoheren (gagasan satu dengan yang lain tidak logis, tidak berhubungan, secara keseluruhan tidak dapat dimengerti)

d) Klien tampak waspada

e) Klien kehilangan selera makan

c. Kontrol Pikir

1) DS :

a) Klien mengatakan pikirannya dikontrol dari luar

b) Klien tidak mampu mengambil keputusan

2) DO : - Perilaku klien tampak seperti isi wahamnya

a) Klien tampak bingung

b) Klien tampak menarik diri

c) Klien mudah tersinggung

d) Klien mudah marah

e) Klien tampak tidak bisa mengontrol diri sendiri

f) Klien mengalami perubahan pola tidur

g) Inkoheren (gagasan satu dengan yang lain tidak logis, tidak berhubungan, secara keseluruhan tidak dapat dimengerti) 


\subsubsection{Penatalaksanaan Medis}

Menurut Prastika (2014) penatalaksanaan medis waham antara lain :

1. Psikofarmalogi

a. Litium Karbonat

Jenis litium yang paling sering digunakan untuk mengatasi gangguan bipolar, menyusul kemudian litium sitial. Litium masih efektif dalam menstabilkan suasana hati pasien dengan gangguan bipolar. Gejala hilang dalam jangka waktu 1-3 minggu setelah minum obat juga digunakan untuk mencegah atau mengurangi intensitas serangan ulang pasien bipolar dengan riwayat mania.

b. Haloperidol

Obat antipsikotik (mayor tranquiliner) pertama dari turunan butirofenon. Mekanisme kerja yang tidak diketahui. Haloperidol efektif untuk pengobatan kelainan tingkah laku berat pada anak-anak yang sering membangkang dan eksplosif. Haloperidol juga efektif untuk pengobatan jangka pendek, pada anak yang hiperaktif juga melibatkan aktivitas motorik berlebih memiliki kelainan tingkah laku seperti: Impulsif, sulit memusatkan perhatian, agresif, suasana hati yang labil dan tidak tahan frustasi.

c. Karbamazepin

Karbamazepin terbukti efektif, dalam pengobatan kejang psikomotor, dan neuralgia trigeminal. Karbamazepin secara kimiawi tidak berhubungan dengan obat antikonvulsan lain atau obat lain yang digunakan untuk mengobati nyeri pada neuralgia trigeminal

1. Pasien hiperaktif atau agitasi anti psikotik potensi rendah Penatalaksanaan ini berarti mengurangi dan menghentikan agitasi untuk pengamanan pasien. Hal ini menggunakan penggunaan obat anti psikotik untuk pasien waham. 
2. Antipsikosis atipikal (olanzapin, risperidone). Pilihan awal Risperidone tablet $1 \mathrm{mg}, 2 \mathrm{mg}$, $3 \mathrm{mg}$ atau Clozapine tablet 25mg, 100mg. Keuntungan

3. Tipikal (klorpromazin, haloperidol), klorpromazin 25100mg. Efektif untuk menghilangkan gejala positif.

4. Penarikan diri selama potensi tinggi seseorang mengalami waham. Dia cenderung menarik diri dari pergaulan dengan orang lain dan cenderung asyik dengan dunianya sendiri (khayalan dan pikirannya sendiri). Oleh karena itu, salah satu penatalaksanaan pasien waham adalah penarikan diri yang potensial, Hal ini berarti penatalaksanaannya penekanankan pada gejala dari waham itu sendiri, yaitu gejala penarikan diri yang berkaitan dengan kecanduan morfin biasanya sewaktuwaktu sebelum waktu yang berikutnya, penarikan diri dari lingkungan sosial

5. ECT tipe katatonik Electro Convulsive Therapy (ECT) adalah sebuah prosedur dimana arus listrik melewati otak untuk pelatihan kejang singkat. Hal ini menyebabkan perubahan dalam kimiawi otak yang dapat mengurangi penyakit mental tertentu, seperti skizofrenia katatonik. ECT bisa menjadi pilihan jika gejala yang parah atau jika obat-obatan tidak membantu meredakan episode katatonik.

6. Psikoterapi Walaupun obat-obatan penting untuk mengatasi pasien waham, namun psikoterapi juga penting. Psikoterapi mungkin tidak sesuai untuk semua orang, terutama jika gejala terlalu berat untuk terlibat dalam proses terapi yang memerlukan komunikasi dua arah. Yang termasuk dalam psikoterapi adalah terapi perilaku, terapi kelompok, terapi keluarga, terapi supportif. 


\subsection{Konsep Dasar Asuhan Keperawatan}

\subsubsection{Pengkajian}

1. Identifikasi klien

Perawat yang merawat klien melakukan perkenalan dan kontrak dengan klien tentang: Nama klien, panggilan klien, Nama perawat, tujuan, waktu pertemuan, topik pembicaraan.

2. Keluhan utama/alasan masuk

Tanyakan pada keluarga/klien hal yang menyebabkan klien dan keluarga datang ke Rumah Sakit, yang telah dilakukan keluarga untuk mengatasi masalah dan perkembangan yang dicapai.

3. Tanyakan pada klien/keluarga, apakah klien pernah mengalami gangguan jiwa pada masa lalu, pernah melakukan, mengalami, penganiayaan fisik, seksual, penolakan dari lingkungan, kekerasan dalam keluarga dan tindakan kriminal. Dapat dilakukan pengkajian pada keluarga faktor yang mungkin mengakibatkan terjadinya gangguan:

a. Psikologis

Keluarga, pengasuh dan lingkungan klien sangat mempengaruhi respon psikologis dari klien.

b. Biologis

Gangguan perkembangan dan fungsi otak atau SSP, pertumbuhan dan perkembangan individu pada prenatal, neonatus dan anak-anak.

c. Sosial Budaya

Seperti kemiskinan, konflik sosial budaya (peperangan, kerusuhan, kerawanan), kehidupan yang terisolasi serta stress yang menumpuk.

4. Aspek fisik/biologis

Mengukur dan mengobservasi tanda-tanda vital: TD, nadi, suhu, pernafasan. Ukur tinggi badan dan berat badan, kalau perlu kaji fungsi organ kalau ada keluhan 


\section{Aspek psikososial}

a. Membuat genogram yang memuat paling sedikit tiga generasi yang dapat menggambarkan hubungan klien dan keluarga, masalah yang terkait dengan komunikasi, pengambilan keputusan dan polaasuh.

b. Konsep diri

1) Citra tubuh: mengenai persepsi klien terhadap tubuhnya, bagian yang disukai dan tidak disukai.

2) Identitas diri: status dan posisi klien sebelum dirawat, kepuasan klien terhadap status dan posisinya dan kepuasanklien sebagai laki- laki/perempuan.

3) Peran: tugas yang diemban dalam keluarga /kelompok dan masyarakat dan kemampuan klien dalam melaksanakan tugas tersebut.

4) Ideal diri: harapan terhadap tubuh, posisi, status, tugas, lingkungan dan penyakitnya.

5) Harga diri: hubungan klien dengan orang lain, penilaian dan penghargaan orang lain terhadap dirinya, biasanya terjadi pengungkapan kekecewaan terhadap dirinya sebagai wujud harga diri rendah.

c. Hubungan sosial dengan orang lain yang terdekat dalam kehidupan, kelompok yang diikuti dalam masyarakat

d. Spiritual, mengenai nilai dan keyakinan dan kegiatan ibadah,.

6. Status mental

Nilai penampilan klien rapi atau tidak, amati pembicaraan klien, aktvitas motori klien, alam perasaan klien (sedih, takut, khawatir), afek klien, interaksi selama wawancara, persepsi klien, proses pikir, isi pikir, tingkat kesadaran, memori, tingkat konsentasi dan berhitung, kemampuan penilaian dan daya tilik diri.

7. Proses pikir.

Proses pikir dalam berbicara jawaban klien kadang meloncat-loncat dari satu topik ketopik lainnya, masih ada hubungan yang tidak logis dan 
tidak sampai pada tujuan (flight ofideas) kadang-kadang klien mengulang pembicaraan yang sama (persevere)

Masalah keperawatan: Gangguan Proses Pikir.

8. Isi Pikir

Contoh isi pikir klien saat diwawancara :

a. Klien mengatakan bahwa dirinya banyak mempunyai pacar, dan pacarnya orang kaya dan bos batu bara Masalah keperawatan : waham kebesaran.

b. Klien mengatakan alasan masuk RSJ karena sakit liver. Masalah keperawatan : waham somatik.

9. Kebutuhan Persiapan Pulang

a. Kemampuan makan klien, klien mampu menyiapkan dan membersihkan alat makan

b. Klien mampu BAB dan BAK, menggunakan dan membersihkan WC serta membersihkan dan merapikan pakaian

c. Mandi klien dengan cara berpakaian, observasi kebersihan tubuh klien.

d. Istirahat dan tidur klien, aktivitas didalam dan diluar rumah

e. Pantau penggunaan obat dan tanyakan reaksi yang dirasakan setelah minum obat.

10. Masalah psikososial dan lingkungan

Dari data keluarga atau klien mengenai masalah yang dimiliki klien.

11. Pengetahuan

Data didapatkan melalui wawancara dengan klien kemudian tiap bagian yang dimiliki klien disimpulkan dalam masalah.

12. Aspek medic

Terapi yang diterima oleh klien: ECT, terapi antara lain seperti terapi psikomotor, terapi tingkah laku, terapi keluarga, terapi spiritual, terapi okupasi, terapi lingkungan. Rehabilitasi sebagai suatu refungsionalisasi dan perkembangan klien supaya dapat melaksanakan sosialisasi secara wajar dalam kehidupan bermasyarakat. 


\subsubsection{Diagnosa Keperawatan}

Menurut Damaiyanti (2012) Masalah keperawatan yang sering muncul pada klien waham adalah: Gangguan proses pikir: waham, Kerusakan komunikasi verbal dan Harga diri rendah kronik.

\subsubsection{Rencana Keperawatan}

Rencana Keperawatan yang diberikan pada klien tidak hanya berfokus pada masalah waham sebagai diagnosa penyerta lain. Hal ini dikarenakan tindakan yang dilakukan saling berkontribusi terhadap tujuan akhir yang akan dicapai. Rencana tindakan keperawatan pada klien dengan diagnosa gangguan proses pikir : waham yaitu (Keliat, 2009) :

1. Bina hubungan saling percaya

Sebelum memulai mengkaji pasien dengan waham, saudara harus membina hubungan saling percaya terlebih dahulu agar pasien merasa aman dan nyaman saat berinteraksi dengan saudara. Tindakan yang harus saudara lakukan dalam rangka membina hubungan saling percaya adalah:

a. Mengucapkan salam terapeutik

b. Berjabat tangan

c. Menjelaskan tujuan interaksi

d. Membuat kontrak topik, waktu dan tempat setiap kali bertemu pasien.

2. Bantu orientasi realita

a. Tidak mendukung atau membantah waham pasien

b. Yakinkan pasien berada dalam keadaan aman

c. Observasi pengaruh waham terhadap aktivitas sehari-hari

d. Jika pasien terus menerus membicarakan wahamnya dengarkan tanpa memberikan dukungan atau menyangkal sampai pasien berhenti membicarakannya

e. Berikan pujian bila penampilan dan orientasi pasien sesuai dengan realitas. 
f. Diskusikan kebutuhan psikologis/emosional yang tidak terpenuhi sehingga menimbulkan kecemasan, rasa takut dan marah.

g. Tingkatkan aktivitas yang dapat memenuhi kebutuhan fisik dan emosional pasien

h. Berdikusi tentang kemampuan positif yang dimiliki

i. Bantu melakukan kemampuan yang dimiliki

j. Berdiskusi tentang obat yang diminum

k. Melatih minum obat yang benar

\subsubsection{Implementasi keperawatan}

Implementasi disesuaikan dengan rencana tindakan keperawatan. Pada situasi nyata sering pelaksanaan jauh berbeda dengan rencana hal ini terjadi karena perawat belum terbiasa menggunakan rencana tertulis dalam melaksanakan tindakan keperawatan Dalami (2009). Adapun pelaksanaan tindakan keperawatan jiwa dilakukan berdasarkan Strategi Pelaksanaan (SP) yang sesuai dengan masing-masing maslaah utama. Pada masalah gangguan proses pikir : waham terdapat 4 macam SP yaitu : SP 1 Pasien : Membina hubungan saling percaya, latihan orientasi realita : orientasi orang, tempat, dan waktu serta lingkungan sekitar.

SP 2 Pasien : Mengajarkan cara minum obat secara teratur SP 3 Pasien : Mengidentifikasi kebutuhan yang tidak terpenuhi dan cara memenuhi kebutuhan; mempraktekkan pemenuhan kebutuhan yang tidak terpenuhi

SP 4 Pasien : Mengidentifikasi kemampuan positif pasien yang dimiliki dan membantu mempraktekkannya

\subsubsection{Evaluasi Keperawatan}

Evaluasi adalah proses yang berkelanjutan untuk menilai efek dari tindakan keperawatan klien (Dalami, 2009). Evaluasi dilakukan terus menerus pada respon klien terhadap tindakan yang telah dilaksanakan, evaluasi dapat dibagi dua jenis yaitu : evaluasi proses atau formatif 
dilakukan selesai melaksanakan tindakan. Evaluasi hasil atau sumatif dilakukan dengan membandingkan respon klien pada tujuan umum dan tujuan khusus yang telah ditentukan.

Menurut Yusuf (2015) evaluasi yang diiharapkan pada asuhan keperawatan jiwa dengan gangguan proses pikir adalah:

1. Pasien mampu melakukan hal berikut:

a. Mengungkapkan keyakinannya sesuai dengan kenyataan.

b. Berkomunikasi sesuai kenyataan.

c. Menggunakan obat dengan benar dan patuh.

2. Keluarga mampu melakukan hal berikut:

a. Membantu pasien untuk mengungkapkan keyakinannya sesuai kenyataan.

b. Membantu pasien melakukan kegiatan-kegiatan sesuai dengan kemampuan dan kebutuhan pasien.

c. Membantu pasien menggunakan obat dengan benar dan patuh. 


\section{BAB 3}

\section{TINJAUAN KASUS}

\subsection{Identitas Klien}

$\begin{array}{ll}\text { Inisial } & : \text { Tn.A } \\ \text { Jenis kelamin } & : \text { Laki-Laki } \\ \text { Umur } & : \text { 29 Tahun } \\ \text { Agama } & : \text { Buddha } \\ \text { Status } & : \text { Belum Menikah } \\ \text { Tanggal pengkajian } & : \text { 25 Februari 2021 } \\ \text { Informent } & : \text { Status klien dan komunikasi dengan klien. }\end{array}$

\subsection{Alasan Masuk Yayasan Pemenang Jiwa}

Alasan klien masuk Yayasan Pemenang Jiwa Sumatera adalah karena klien sering bermain game warnet berlarut-larut setiap harinya sehingga dia putus sekolah serta selalu beranggapan/berfikir bahwa dirinya adalah Andi Lau dan Ultraman.

\subsection{Faktor Predisposisi}

Klien sebelumnya tidak pernah mengalami gangguan jiwa. Klien dibawa oleh tetangga nya ke Yayasan Pemenang Jiwa Sumatera tahun 2018. Klien tidak pernah mengalami penganiayaan maupun kekerasan. Keluarga klien tidak ada yang pernah mengalami gangguan jiwa. Klien mengatakan ia sangat menyesal kerena telah membuat kedua orang tuanya menjadi sering bertengkar karena kelakuannya di masa lalu yang sering bermain ke warnet dan menghabiskan waktu dan uang. Klien sedih karena klien berfikir bahwa orang tua nya menjadi sakit dan meninggal karena memikirkan kelakuannya yang tidak benar. Klien juga mengatakan bahwa dirinya menyesal dan malu karena ia tidak tamat SD, ia merasa bahwa hidupnya menjadi terbengkalai.

Masalah Keperawatan: Koping individu inefektif 


\subsection{Fisik}

Klien tidak memiliki keluhan fisik, saat dilakukan pemeriksaan tanda-tanda vital, didapatkan hasil TD : 130/80 mmHg ; $\mathrm{N}: 80 \mathrm{x} / \mathrm{i} ; \mathrm{S}: 36,2^{\circ} \mathrm{C}$; $\mathrm{P}: 22 \mathrm{x} / \mathrm{i}$. Klien memiliki tinggi badan $175 \mathrm{~cm}$ dan berat badan $75 \mathrm{Kg}$.

\subsection{Psikososial}

\subsubsection{Genogram}

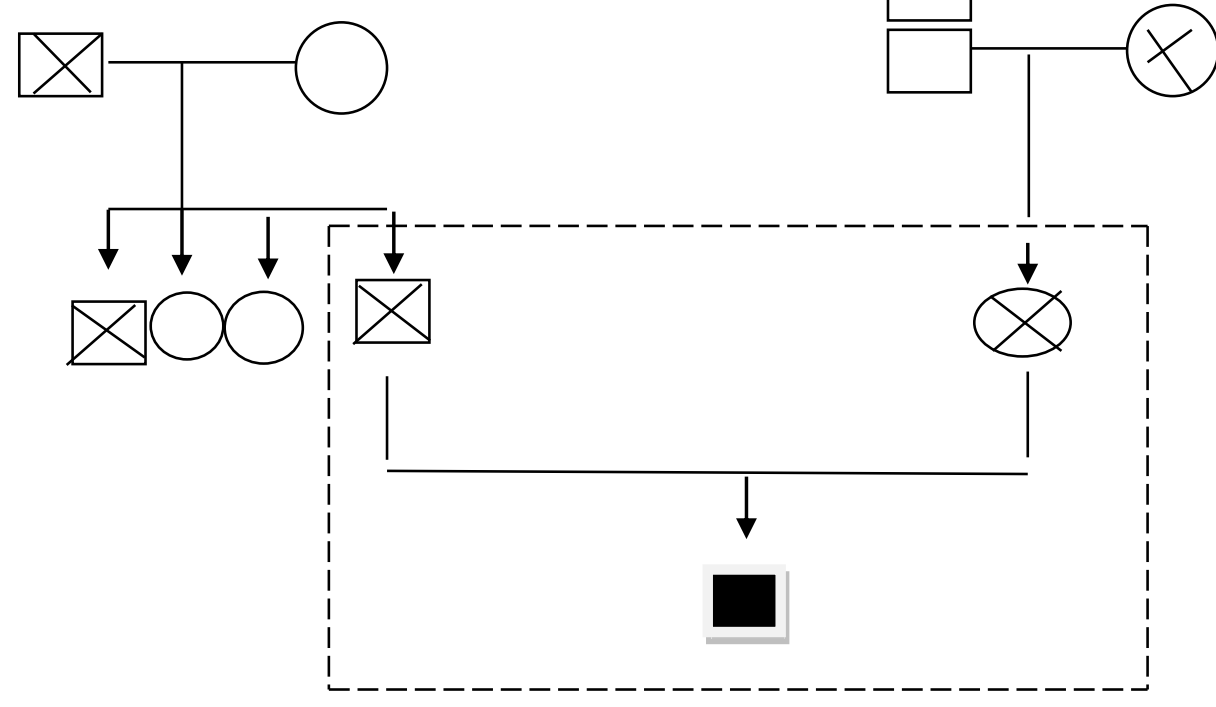

Penjelasan :

Klien merupakan anak tunggal dan kedua orang tuanya sudah meninggal. Dan ia hanya dibawah tanggungan abang sepupunya.

Keterangan :

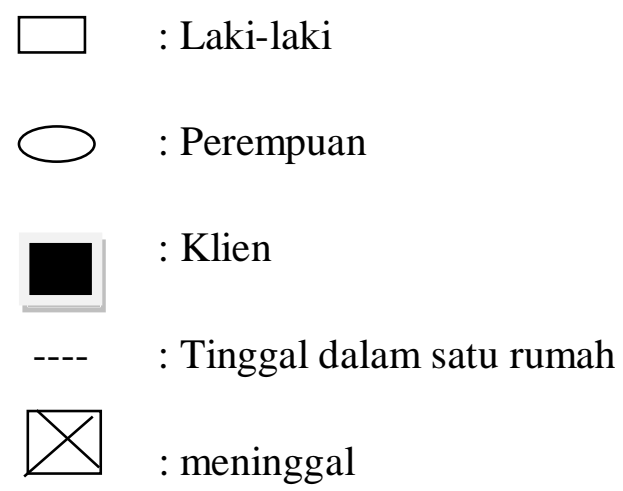




\subsubsection{Konsep diri}

a. Gambaran diri : Klien menyukai seluruh tubuhnya dan tidak ada yang cacat

b. Identitas : Klien anak tunggal, klien hanya lulusan SD yang saat ini tidak memiliki pekerjaan

c. Peran : Klien berperan sebagai anak

d. Ideal diri : Klien merasa malu karena klien dirawat di Yayasan Pemenang Jiwa Sumatera dan ingin cepat pulang ke rumah. Dia sangat malu hanya lulus SD.

e. Harga diri : Klien mengatakan merasa malu berada di Yayasan Pemenang Jiwa Sumatera dan merasa bosan dan sedih.

\section{Masalah keperawatan: Gangguan konsep diri : Harga diri rendah}

\subsubsection{Hubungan sosial}

Klien mengganggap bahwa keluarganya adalah orang yang sangat berarti dalam hidupnya, terutama orangtuanya dan abang sepupunya. Klien tidak mengikuti kegiatan di kelompok/masyarakat. Klien mengatakan mempunyai berhubungan baik dengan orang lain dan teman-temannya.

\subsubsection{Spiritual}

a. Nilai dan Keyakinan : Klien beragama Buddha dan yakin dengan agamanya.

b. Kegiatan Ibadah : Klien ikut melakukan ibadah selama dirawat.

\subsubsection{Status Mental}

1. Penampilan

Penjelasan : Klien rapi dan bersih, klien mandi 2x sehari menggunakan shampo dan sabun dan menggosok gigi nya.

2. Pembicaraan

Penjelasan : Klien saat diberikan pertanyaan kadangkadang menjawab tidak nyambung.

Masalah keperawatan : : Waham (Waham Kebesaran) 
3. Aktivitas Motorik

Penjelasan

: Klien tampak tegang ketika diajak

berkomunikasi

Masalah keperawatan : Waham (Waham Kebesaran)

4. Alam perasaan

Penjelasan

: Klien sedih karena tinggal di yayasan, terlebih keluarga jarang datang menjenguk. Klien sangat rindu dengan keluarganya.

Masalah keperawatan : Harga Diri Rendah

5. Afek

Penjelasan

: Afek klien datar, klien menjawab

pertanyaan dari perawat

6. Interaksi selama wawancara

Penjelasan : Selama komunikasi, klien selalu mempertahankan bahwa dirinya adalah seorang artis Andi Lau dan Ultraman.

7. Persepsi

Penjelasan $\quad$ Klien tidak mengalami gangguan persepsi sensori

8. Proses Pikir

Penjelasan : Klien berfikir seperti Flight of idea. Klien pada saat di ajak berbicara tidak nyambung, menjawabnya tidak tepat pada fokus pertanyaan dari pembicaraan.

Masalah keperawatan : Waham (Waham Kebesaran)

9. Isi pikir

Penjelasan $\quad$ : Klien mengatakan terobsesi menjadi seorang artis yaitu Andi Lau dan Ultraman. Klien merasa dirinya ganteng.

Masalah Keperawatan : : Waham (Waham Kebesaran)

10. Tingkat kesadaran

Penjelasan :Klien tampak bingung dengan sekelilingnya karena teman-temannya bukan artis dan ultraman. 
Masalah keperawatan $\quad$ : Waham (Waham Kebesaran)

11. Memori

Penjelasan

: Klien tidak ada gangguan daya ingat.

Klien mampu mengingat suatu hal.

12. Tingkat konsentrasi berhitung

Penjelasan $\quad$ : Klien mampu berkonsentrasi cukup baik dan klien mampu berhitung sederhana tanpa bantuan orang lain.

13. Kemampuan penilaian

Penjelasan

: Klien mampu menilai mana yang lebih diutamakan dalam mengambil keputusan.

14. Daya tilik diri

Penjelasan

: Klien merasa bahwa dirinya adalah

seorang artis dan ultraman walaupun dia bukanlah seorang tokoh seperti yang ia katakan.

Masalah keperawatan : : Waham (Waham Kebesaran)

\subsection{Kebutuhan Persiapan Pulang}

1. Makan, Minum, BAB/BAK

Pasien dapat mengambil makan dan minum dan dapat kekamar mandi untuk $\mathrm{BAB} / \mathrm{BAK}$.

2. Mandi, berpakaian/berhias

Pasien mengatakan dapat mandi dan berpakaian secara mandiri

3. Istirahat dan tidur

Tidur siang lama : 13.00 WIB s/d 16.30 WIB, tidur malam lama : 22.00 WIB s/d 05.00 WIB, kegiatan sebelum/sesudah : Beribadah

\subsection{Mekanisme Koping}

Klien mampu berbicara dengan orang lain dengan baik, klien juga mampu berolahraga. Pada saat diajak berbicara reaksi lambat/berlebih. 


\subsection{Masalah Psikososial dan Lingkungan}

Klien mengatakan bahwa ia tidak tamat SD, Klien mengatakan pernah gagal dalam pekerjaannya.

\subsection{Pengetahuan Kurang Tentang Gangguan Jiwa}

Klien tidak mengetahui tentang gangguan jiwa yang di alaminya dan obat yang dikonsumsinya.

\subsection{Aspek Medik}

Diagnosa medis : Skizofrenia Paranoid

Terapi medis yang diberikan:

a. Resperidon tablet $2 \mathrm{mg} 3 \times 1$

b. Depakote tablet $3 \times 1$

\subsection{Analisis Data}

\begin{tabular}{|c|c|c|}
\hline No & Data & Masalah Keperawatan \\
\hline 1 & $\begin{array}{l}\text { Subjektif: } \\
\text { Klien mengatakan bahwa ia adalah artis, dan } \\
\text { ultraman yang tidak sesuai dengan kenyataan } \\
\text { Objektif: } \\
\text { Klien tampak bingung, banyak bicara dan } \\
\text { hiperaktif }\end{array}$ & $\begin{array}{c}\text { Gangguan Proses Pikir : } \\
\text { Waham (Waham } \\
\text { Kebesaran) }\end{array}$ \\
\hline 2 & $\begin{array}{l}\text { Subjektif: } \\
\text { Klien merasa dibuang oleh keluarganya dan } \\
\text { merasa minder dengan orang lain karena di } \\
\text { rawat dirumah sakit jiwa } \\
\text { Objektif: } \\
\text { Klien tampak malu, karena dirinya tidak ada } \\
\text { pekerjaan dan hanya tamatan SD. Klien juga } \\
\text { malu karena belum menikah. }\end{array}$ & $\begin{array}{l}\text { Gangguan Konsep Diri : } \\
\text { Harga diri rendah }\end{array}$ \\
\hline 3 & $\begin{array}{l}\text { Subjektif: } \\
\text { 1. Klien mengatakan ia sangat menyesal } \\
\text { kerena telah membuat kedua orang } \\
\text { tuanya menjadi sering bertengkar karena } \\
\text { kelakuannya di masa lalu yang sering }\end{array}$ & $\begin{array}{l}\text { Koping individu } \\
\text { inefektif }\end{array}$ \\
\hline
\end{tabular}




\begin{tabular}{|l|l|} 
bermain ke warnet dan menghabiskan \\
waktu dan uang. \\
2. Klien sedih karena klien berfikir bahwa \\
orang tua nya menjadi sakit dan \\
meninggal karena memikirkan \\
kelakuannya yang tidak benar. \\
Objektif: \\
Klien tampak sedih
\end{tabular}

\subsection{Diagnosa Keperawatan}

a. Gangguan Proses Pikir : Waham (Waham Kebesaran)

b. Gangguan Konsep Diri : Harga Diri Rendah

c. Koping Individu Inefektif

\subsection{Pohon Masalah}

Kerusakan Komunikasi Verbal<smiles>[CH]=C</smiles>

Perubahan proses pikir: Waham<smiles>[CH]</smiles>

Gangguan Konsep Diri : Harga Diri Rendah<smiles></smiles>

Koping Individu Inefektif

\subsection{Intervensi Keperawatan}

\begin{tabular}{|c|c|c|}
\hline No & Diagnosa & Intervensi \\
\hline 1 & $\begin{array}{l}\text { Gangguan Proses Pikir: } \\
\text { Waham (Waham Kebesaram) } \\
\text { Subjektif: } \\
\text { Klien mengatakan bahwa ia } \\
\text { adalah artis, dan ultraman } \\
\text { yang tidak sesuai dengan } \\
\text { kenyataan } \\
\text { Objektif: } \\
\text { Klien tampak bingung, } \\
\text { banyak bicara dan hiperaktif }\end{array}$ & $\begin{array}{l}\text { Sp1: } \\
\text { Latihan orientasi realita : orientasi } \\
\text { orang, tempat, dan waktu serta } \\
\text { lingkungan sekitar } \\
\text { Sp2: } \\
\quad \text { Minum obat secara teratur } \\
\text { Sp 3: } \\
\quad \text { Melatih cara pemenuhan kebutuhan } \\
\quad \text { dasar } \\
\text { Sp 4: } \\
\text { Melatih kemampuan positif yang dimiliki }\end{array}$ \\
\hline 2 & $\begin{array}{l}\text { Harga Diri Rendah } \\
\text { Subjektif : }\end{array}$ & $\begin{array}{l}\text { Sp1: } \\
\text { Mengidentifikasi kemampuan dan aspek }\end{array}$ \\
\hline
\end{tabular}




\begin{tabular}{|c|c|c|}
\hline & $\begin{array}{l}\text { Klien merasa dibuang oleh } \\
\text { keluarganya dan merasa } \\
\text { minder dengan orang lain } \\
\text { karena di rawat di Yayasan } \\
\text { Pemenang Jiwa Sumatera } \\
\text { Objektif: } \\
\text { Klien tampak malu karena } \\
\text { belum ada pekerjaan, dan ia } \\
\text { malu karena hanya tamatan } \\
\text { SD. Dan ia malu belum } \\
\text { menikah. }\end{array}$ & $\begin{array}{l}\text { positif yang dimiliki oleh pasien } \\
\text { Sp 2: } \\
\text { 1. Menilai kemampuan yang dapat } \\
\text { digunakan } \\
\text { 2. Menetapkan / memilih kegiatan sesuai } \\
\text { kemampuan } \\
\text { 3. Melatih kegiatan sesuai kemampuan } \\
\text { yang dipilih } 2 \\
\text { Sp 3: } \\
\text { Melatih kegiatan sesuai kemampuan yang } \\
\text { dipilih } 2 \\
\text { Sp 4: } \\
\text { Melatih kegiatan sesuai kemampuan yang } \\
\text { dipilih } 3\end{array}$ \\
\hline 3 & $\begin{array}{l}\text { Resiko Perilaku Kekerasan } \\
\text { Subjektif: } \\
\text { Klien mengatakan pernah } \\
\text { melempar barang-barang yang } \\
\text { ada dirumahnya, pernah } \\
\text { memukul temannya dan } \\
\text { marah-marah karena px kalah } \\
\text { main game di warnet. } \\
\text { Objektif: } \\
\text { Klien tampak memandang } \\
\text { orang lain dengan tatapan } \\
\text { bermusuhan dan tampak } \\
\text { gelisah. }\end{array}$ & $\begin{array}{l}\text { Sp1: } \\
\text { 1. Identifikasi penyebab, frekuensi } \\
\text { perilaku kekerasan } \\
\text { 2. Mengontrol perilaku kekerasan dengan } \\
\text { tarik nafas dalam dan pukul } \\
\text { kasur/bantal } \\
\text { Sp2: } \\
\text { Kontrol perilaku kekerasan dengan } \\
\text { minum obat secara teratur } \\
\text { Sp 3: } \\
\text { Kontrol perilaku kekerasan dengan } \\
\text { berbicara baik-baik } \\
\text { Sp 4: } \\
\text { Spiritual }\end{array}$ \\
\hline
\end{tabular}

\subsection{Implementasi Dan Evaluasi Keperawatan}

\begin{tabular}{|l|l|l|}
\hline Hari/tgl & \multicolumn{1}{|c|}{ Implementasi } & \multicolumn{1}{c|}{ Evaluasi } \\
\hline Kamis & 1. Data : & S : Senang \\
Pukul & Tanda dan gejala : banyak & O : \\
10:00 WIB & berbicara, hiperaktif, wajah & \multicolumn{1}{c|}{ Klien mampu } \\
& tegang, bingung, inkoheren, flight & melakukan latihan \\
& of idea. Selalu menganggap & orientasi realita : \\
& dirinya Andi Lau dan ultraman. & panggil nama, waktu, \\
& Diagnosa Keperawatan & orang dan \\
& Waham & tempat/lingkungan \\
& & dengan mandiri \\
& & Klien mampu \\
\hline
\end{tabular}




\begin{tabular}{|c|c|}
\hline 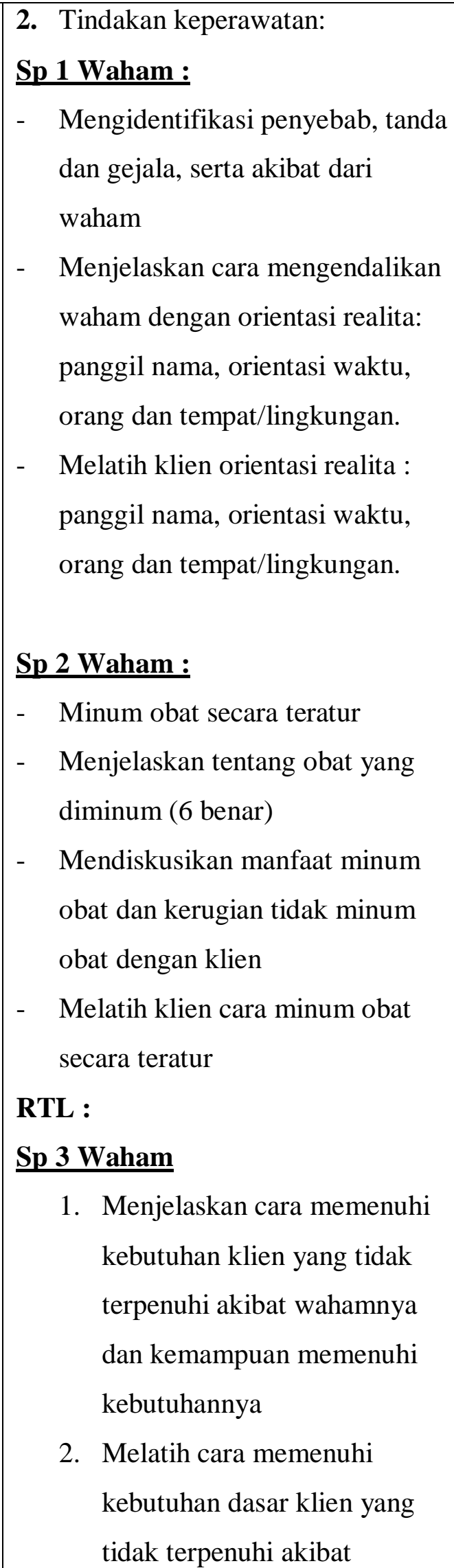 & $\begin{array}{l}\text { mimum obat secara } \\
\text { teratur dan mampu } \\
\text { menyebutkan } \\
\text { manfaat dari obat } \\
\text { yang di minum dan } \\
\text { waktu minum obat } \\
\text { dengan bantuan } \\
\text { A : Waham (+) } \\
\text { P : Latihan : } \\
\text { Orientasi realita : } \\
\text { panggil nama, } \\
\text { orientasi waktu, } \\
\text { orang dan } \\
\text { tempat/lingkungan. } \\
\text { Minum obat secara } \\
\text { teratur } 3 \times 1 \\
\text { Risperidon } 2 \text { mg }(3 \times 1) \\
\text { Depakote } 250 \text { mg ( } 3 \times 1)\end{array}$ \\
\hline
\end{tabular}




\begin{tabular}{|c|c|c|}
\hline & $\begin{array}{l}\text { wahamnya dan kemampuan } \\
\text { memenuhi kebutuhannya }\end{array}$ & \\
\hline $\begin{array}{l}\text { Jumat } \\
\text { 26/02/2021 } \\
\text { Pukul } \\
\text { 10:00 WIB }\end{array}$ & $\begin{array}{l}\text { 1. Data: } \\
\text { Tanda dan gejala : banyak } \\
\text { berbicara, hiperaktif, wajah } \\
\text { tegang.. Selalu menganggap } \\
\text { dirinya Andi Lau dan ultraman. } \\
\text { Diagnosa Keperawatan } \\
\text { Waham } \\
\text { 2. Tindakan keperawatan : } \\
\text { Sp 3 Waham } \\
\text { 1. Menjelaskan cara memenuhi } \\
\text { kebutuhan klien yang tidak } \\
\text { terpenuhi akibat wahamnya } \\
\text { dan kemampuan memenuhi } \\
\text { kebutuhannya } \\
\text { 2. Melatih cara memenuhi } \\
\text { kebutuhan dasar klien yang } \\
\text { tidak terpenuhi akibat } \\
\text { wahamnya dan kemampuan } \\
\text { memenuhi kebutuhannya } \\
\text { 4.RTL: } \\
\text { Sp 4 Waham } \\
\text { - Menjelaskan kemampuan } \\
\text { positif yang dimiliki klien } \\
\text { Mendiskusikan kemampuan } \\
\text { - Melatih kemampuan positif } \\
\text { - }\end{array}$ & 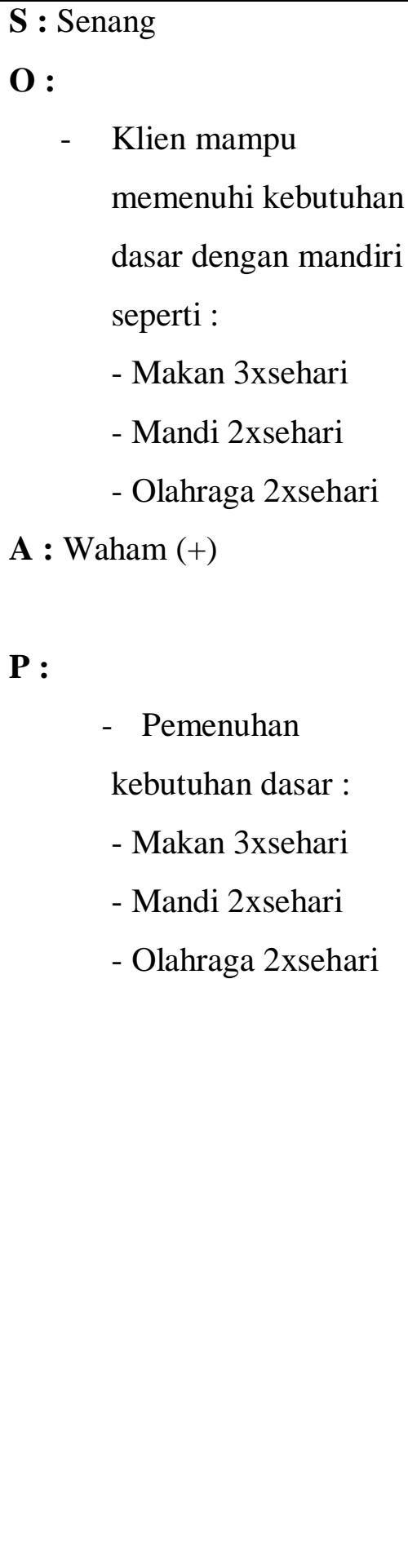 \\
\hline $\begin{array}{l}\text { Sabtu } \\
27 / 02 / 2021 \\
\text { Pukul }\end{array}$ & $\begin{array}{l}\text { 1. Data: } \\
\text { Tanda dan gejala : } \\
\text { Banyak berbicara, hiperaktif, }\end{array}$ & $\begin{array}{l}\text { S: Senang } \\
\text { O : } \\
-\quad \text { Klien mampu }\end{array}$ \\
\hline
\end{tabular}




\begin{tabular}{|c|c|c|}
\hline 10:00 WIB & $\begin{array}{l}\text { bingung. Selalu menganggap } \\
\text { dirinya Andi Lau dan ultraman. } \\
\text { 2. Diagnosa Keperawatan: } \\
\text { Waham } \\
\text { 3. Tindakan keperawatan: } \\
\text { Sp } 4 \text { Waham } \\
\text { - Menjelaskan kemampuan } \\
\quad \text { positif yang dimiliki klien } \\
\text { - Mendiskusikan kemampuan } \\
\quad \text { positif yang dimiliki klien } \\
\text { - Melatih kemampuan positif } \\
\quad \text { yang dipilih } \\
\text { RTL : } \\
\text { Waham : Follow up dan evaluasi SP } \\
\text { 1-4 Waham }\end{array}$ & $\begin{array}{l}\text { melakukan kemampuan } \\
\text { positif yang dimiliki } \\
\text { dengan motivasi } \\
\text { - } \text { Menggambar } \\
\text { - } \quad \text { Menulis cerita } \\
\text { - } \quad \text { Menyanyi } \\
\text { A : Waham (+) } \\
\text { P : } \quad \\
\text { - } \\
\text { Pasien melakukan } \\
\text { kemampuan positif } \\
\text { yang dimiliki : } \\
\text { - Menggambar } \\
\text { - } \quad \text { Menulis cerita } \\
\text { - Menyanyi }\end{array}$ \\
\hline
\end{tabular}




\section{BAB 4 \\ PEMBAHASAN}

Setelah penulis melaksanakan asuhan keperawatan kepada Tn.A dengan waham di Yayasan Pemenang Jiwa Sumatera Sumatera, maka penulis pada BAB ini akan membahas kesenjangan antara teoritis dengan tinjauan kasus. Pembahasan dimulai melalui tahapan proses keperawatan yaitu pengkajian, diagnosa keperawatan, perencanaan, pelaksanaan dan evaluasi.

\subsection{Tahap Pengkajian}

Selama pengkajian dilakukan pengumpulan data dari beberapa sumber, yaitu dari pasien dan tenaga kesehatan di ruangan. Penulis mendapat sedikit kesulitan dalam menyimpulkan data karena keluarga pasien jarang mengunjungi pasien di rumah sakit jiwa. Maka penulis melakukan pendekatan kepada pasien melalui komunikasi teraupetik yang lebih terbuka membantu klien untuk memecahkan perasaannya dan juga melakukan observasi kepada pasien. Adapun upaya tersebut yaitu:

1. Melakukan pendekatan dan membina hubungan saling percaya diri pada klien agar klien lebih terbuka dan lebih percaya dengan menggunakan perasaan.

2. Mengadakan pengkajian klien dengan wawancara

3. Mengadakan pengkajian dengan cara membaca status, melihat buku rawatan dan bertanya kepada pegawai Yayasan Pemenang Jiwa Sumatera Sumatera

Dalam pengkajian ini, penulis tidak menemukan kesenjangan karena ditemukan hal sama seperti diteori: Menurut Herman (2011 dalam Prakasa, 2020) tanda dan gejala waham seperti menolak makan, tidak peduli terhadap perawatan diri, ekspresi wajah yang sedih/gembira/ketakutan, gerakan yang tidak terkontrol, mudah tersinggung, pembicaraan yang tidak sesuai dengan kenyataan dan juga bukan kenyataan, menghindar dari orang lain, mendominasi pembicaraan, dan berbicara kasar. 


\subsection{Tahap perencanaan}

Menurut Keliat (2014) Perencanaan dalam proses keperawatan lebih dikenal dengan rencana asuhan keperawatan yang merupakan tahap selanjutnya setelah pangkajian dan penentuan diagnosa keperawatan. Pada tahap perencanaan penulis hanya menyusun rencana tindakan keperawatan sesuai dengan pohon masalah keperawatan yaitu : Gangguan proses pikir: Waham (Waham Kebesaran). Pada tahap ini antara tinjauan teoritis dan tinjaun kasus tidak ada kesenjangan sehingga penulis dapat melaksanakan tindakan seoptimal mungkin dan didukung dengan tersedianya sarana ruangan perawat yang baik dan adanya bimbingan dan petunjuk dari petugas kesehatan dari Yayasan Pemenang Jiwa Sumatera yang diberikan kepada penulis.

Secara teoritis digunakan cara strategi pertemuan sesuai dengan diagnosa keperawatan yang muncul saat pengkajian. Adapun upaya yang dilakukan penulis yaitu :

1. Waham

a. Mengidentifikasi penyebab, tanda dan gejala, serta akibat dari waham

b. Menjelaskan cara mengendalikan dan melatih waham dengan orientasi realita: panggil nama, orientasi waktu, orang dan tempat/lingkungan.

c. Minum obat secara teratur

d. Menjelaskan tentang obat yang diminum ( 6 benar)

e. Mendiskusikan manfaat minum obat dan kerugian tidak minum obat dengan klien

f. Melatih klien cara minum obat secara teratur

g. Menjelaskan cara memenuhi kebutuhan klien yang tidak terpenuhi akibat wahamnya dan kemampuan memenuhi kebutuhannya

h. Melatih cara memenuhi kebutuhan dasar klien yang tidak terpenuhi akibat wahamnya dan kemampuan memenuhi kebutuhannya

i. Menjelaskan kemampuan positif yang dimiliki klien

j. Mendiskusikan kemampuan positif yang dimiliki klien

k. Melatih kemampuan positif yang dipilih 


\subsection{Tahap Implementasi}

Pada tahap implementasi, penulis hanya mengatasi 1 masalah keperawatan yakni: diagnosa keperawatan Waham di karenakan masalah utama yang dialami klien dengan banyak berbicara, hipersaktif, bingung. Selalu menganggap dirinya Andi Lau dan ultraman.

Pada diagnosa keperawatan Waham dilakukan strategi pertemuan yaitu Latihan Orientasi Realita : Orientasi orang, tempat, dan waktu serta lingkungan sekitar. Strategi pertemuan yang kedua yaitu minum obat secara teratur, strategi pertemuan ketiga yaitu melatih cara pemenuhan kebutuhan dasar, strategi pertemuan ke empat yaitu melatih kemampuan positif yang dimiliki (Keliat, 2014).

\subsection{Tahap Evaluasi}

Pada tinjauan teoritis evaluasi yang diharapkan adalah :

1. Pasien mempercayai perawat sebagai terapis

2. Dapat mengendalikan Waham dengan melatih orientasi realita : orientasi orang, tempat, dan waktu serta lingkungan sekitar.

3. Dapat mengendalikan Waham dengan cara minum obat secara teratur

4. Dapat mengendalikan Waham dengan melatih cara pemenuhan kebutuhan dasar

5. Dapat mengendalikan Waham dengan melatih kemampuan positif yang dimiliki

Pada tinjauan kasus evaluasi yang dihasilkan adalah :

1. Klien sudah dapat mengendalikan Waham dengan melatih orientasi realita : orientasi orang, tempat, dan waktu serta lingkungan sekitar.

2. Klien dapat mengendalikan Waham dengan cara minum obat secara teratur

3. Klien dapat mengendalikan Waham dengan melatih cara pemenuhan kebutuhan dasar

4. Klien dapat mengendalikan Waham dengan melatih kemampuan positif yang dimiliki. 


\section{BAB 5}

\section{KESIMPULAN DAN SARAN}

\subsection{Kesimpulan}

Proses keperawatan merupakan metode ilmiah dalam menjalankan proses keperawatan dan menyelesaikan masalah secara sistematis yang digunakan oleh perawat dan peserta didik keperawatan. Penerapan keperawatan dapat meningkatkan otonomi, percaya diri, cara berfikir yang logis, ilmiah, sistematis dan memperlihatkan tanggung jawab dan tanggung gugat serta pengembangan diri perawat. Disamping itu klien dapat melaksanakan mutu pelayanan keperawatan yang baik khususnya pada klien waham, maka dapat diambil kesimpulan sebagai berikut :

1. Pengkajian yang dilaksanakan tidak banyak berbeda dengan pengkajian teoritis maupun penulis tidak mendapat kesulitan dalam pengkajian klien.

2. Dalam usaha mengatasi masalah yang dihadapi klien penulis menyusun tindakan keperawatan sesuai dengan teoritis begitu juga dengan SP.

3. Dalam pelaksanaan tindakan keperawatan disesuaikan dengan perencanaan dan dapat dilaksanakan walaupun belum optimal.

4. Pada tahap evaluasi terhadap tindakan keperawatan masalah yang dihadapi klien tidak teratasi semua sesuai dengan masalah klien.

\subsection{Saran}

1. Bagi Mahasiswa

Hendaknya mahasiswa/i dapat melakukan askep sesuai dengan tahapantahapan dari Standar Operasional Prosedur (SOP) dengan baik dan benar yang diperoleh selama masa pendidikan baik di akademik maupun dilapangan praktek.

2. Bagi Pasien

Diharapkan pasien dapat menerapkan terapi yang telah diberikan baik secara medik maupun terapi keperawatan yang telah diajarkan demi percepatan penyembuhan penyakit dengan masalah gangguan jiwa. 
3. Bagi Perawat

Diharapkan dapat menerapkan komunikasi terapeutik dalam pelaksanaan strategi pertemuan 1-4 pada klien dengan waham sehingga dapat mempercepat proses pemulihan klien.

4. Bagi Keluarga

Agar keluarga selalu memberikan motivasi kepada klien dan juga perawatan gangguan proses pikir: waham kebesaran dirumah.

5. Bagi Institusi Pendidikan

Dapat meningkatkan bimbingan klinik kepada mahasiswa profesi ners sehingga mahasiswa semakin mampu dalam melakukan asuhan keperawatan pada pasien-pasien yang mengalami waham kebesaran

6. Bagi Rumah Sakit

Laporan ini diharapkan dapat menjadi acuan dan referensi dalam memberikan asuhan keperawatan pada klien dengan waham kebesaran 


\section{DAFTAR PUSTAKA}

Asis, S. J. De. (2018). Psychiatric Disorders Late in Life. Psychiatric Disorders

Late in Life, 11-20. https://doi.org/10.1007/978-3-319-73078-3

Bell, V., Raihani, N., \& Wilkinson, S. (2019). De-Rationalising Delusions. 1-34. https://doi.org/10.1177/2167702620951553

Darmiyanti, A. (2012). Analisa Terapi Aktivitas Kelompok Sosialisasi Sesi Ii Pada Tn. A Dengan Gangguan Proses Pikir: Waham Studi Kasus di Ruang 23 Psikiatri RSUD Saiful Anwar Malang (Doctoral dissertation, University of Muhammadiyah Malang). http://eprints.umm.ac.id/id/eprint/29871

Dalami, E., ROCHIMAH, N., SURYATI, K. R., \& LESTARI, W. (2009). Asuhan Keperawatan klien dengan gangguan jiwa.

Direja, A. H. (2011). Buku ajar asuhan keperawatan jiwa.

Eriawan, A. (2019). Asuhan Keperawatan Pada Klien Tn "O” Yang Mengalami Bipolar Dengan Masalah Keperawatan Waham Paranoid Di Ruangan Palm Rumah Sakit Khusus Daerah Dadi Provinsi Sulawesi Selatan Tahun 2019. https://lib.akpermpd.ac.id/index.php?p=show detail\&id=1451

Hendarsyah, F. (2016). Diagnosis dan tatalaksana skizofrenia paranoid dengan gejala-gejala positif dan negatif. Jurnal Medula, 4(3), 57-62.

Keliat, B. A., dkk. (2019). Asuhan Keperawatan Jiwa. Jakarta: Penerbit Buku Kedokteran EGC.

Keliat, B. A. (2009). Model praktik keperawatan profesional jiwa. Jakarta: EGC.

Keliat B, dkk. (2014). Proses Keperawatan Jiwa Edisi II. Jakarta: EGC

Keliat, B.A., \& Pawirowiyono, A. (2015). Keperawatan Jiwa Terapi Aktivitas Kelompok Edisi 2. Jakarta: EGC.

Pardede, J. A., \& Siregar, R. A. (2016). Pendidikan Kesehatan Kepatuhan Minum Obat Terhadap Perubahan Gejala Halusinasi Pada Klienskizofrenia. Mental Health, 3(1).

Pardede, J. A., Keliat, B. A., \& Yulia, I. (2015). Kepatuhan dan Komitmen Klien Skizofrenia Meningkat Setelah Diberikan Acceptance And Commitment Therapy dan Pendidikan Kesehatan Kepatuhan Minum Obat. Jurnal Keperawatan Indonesia, 18(3), 157-166. https://doi.org/10.7454/jki.v18i3.419

Prakasa, A., \& Milkhatun, M. (2020). Analisis Rekam Medis Pasien Gangguan Proses Pikir Waham dengan Menggunakan Algoritma C4. 5 di Rumah Sakit Atma Husada Mahakam Samarinda.Borneo Student Research (BSR), 2(1),

8-15. https://scholar.googleusercontent.com/scholar?q=cache:98 XaqlexBUJ:sc holar.google.com/+prevalensi+WAHAM\&hl=id\&as_sdt=0,5

Prastika, Y., Mundakir, S. K., \& Reliani, S. K. (2014). Asuhan Keperawatan Jiwa Pada Pasien Waham Kebesaran Dengan Diagnosa Medis Skizofrenia Hebefrenik Di Ruang Flamboyan Rs Jiwa Menur Surabaya (Doctoral dissertation, Universitas Muhammadiyah Surabaya). http://repository.umsurabaya.ac.id/361/

Rowland, dkk. (2019). Short-term outcome of first episode delusional disorder in an early intervention population. Schizophrenia Research, 204(xxxx), 7279. https://doi.org/10.1016/j.schres.2018.08.036 
Skelton, M., Khokhar, W. A., \& Thacker, S. P. (2015). Treatments for delusional disorder. Schizophrenia Bulletin. https://doi.org/10.1093/schbul/sbv080

Sofian, R. (2017). Asuhan Keperawatan jiwa dengan kasus waham kebesaran pada Tn. K di RSJ Radjiman Wediodiningrat Lawang (Doctoral dissertation, STIKes Maharani Malang).

Stuart dan Laraia. (2005). Principles dan Pratice of Psychiatric Nursing. 8th Edition.

St.Louis:Mosby.https://www.scirp.org/(S(vtj3fa45qm1ean45vvffcz55))/ref erence/ReferencesPapers.aspx?ReferenceID $=1642636$

Townsend, M. C., \& Morgan, K. I. (2017). Psychiatric mental health nursing: Concepts of care in evidence-based practice. FA Davis.

Victoryna, F., Wardani, I. Y., \& Fauziah, F. (2020). Penerapan Standar Asuhan Keperawatan Jiwa Ners untuk Menurunkan Intensitas Waham Pasien Skizofrenia. Jurnal Keperawatan Jiwa, 8(1), 45-52. https://doi.org/10.26714/jkj.8.1.2020.45-52

World Health Organization. (2016). Scizofrenia. : https://www.who.int/newsroom/fact-sheets/detail/schizophrenia

Yusuf, A., dkk. (2015). Buku ajar keperawatan kesehatan jiwa. Jakarta : Salemba. 